\title{
Reshaping the design education for new age learners
}

\author{
Ceren Polat ${ }^{1 \mathrm{a}}$, Eray Bozkurt ${ }^{2}$ \\ ${ }^{1}$ Yasar University, Department of Interior Architecture and Environmental Design, Selcuk Yasar \\ Kampusu, Bornova, Izmir, Turkey \\ ${ }^{2}$ Yaşar University, Department of Architecture Selcuk Yasar Kampusü Bornova, İzmir, Turkey
}

\begin{abstract}
Various design philosophies such as modernism, postmodernism, deconstructivism appeared following industrialization. Such developments have required today, including several research techniques in the design process. To discover "human being" on a user basis in general, the sciences of design have started to analyse researches and data in different disciplines as psychology, sociology, and environmental psychology. Embedding evolving technology to this process, such data are used to develop new topics in design like intangible design, interactive art, computational design, etc. The process of analysing and improving education methods may also add improvement of research methods to the agenda. Creativity, innovation and variations in design sail for infinite choices together with developing research methods, changing skilled new generation and developing technologies. The aim of this research is to point out the failures of design education for the new age learners.
\end{abstract}

Keywords. Design education; education methods; research methods; new generation; creativity.

\section{Introduction}

At the beginning of the 20th century, the Industrial Revolution and its technological developments inspired the designers. These interests initiated the foundations of the Modern design movement. In particular, the Bauhaus school generated new ideas in the visual arts with the development of technology and industry. The Bauhaus school made many publications and studies. In the basic course content, shape, material, and colour

${ }^{\text {a }}$ Corresponding author: ceren.polat@yasar.edu.tr

(C) The Authors, published by EDP Sciences. This is an open access article distributed under the terms of the Creative Commons Attribution License 4.0 (http://creativecommons.org/licenses/by/4.0/). 
subjects were trained with an emphasis on texture and form. The studies at the Bauhaus school influenced many design departments worldwide.

The international conferences discussed the 21 st Century design education. In these encounters, teaching methods, changing generation, creativity, increasing data, and research methodologies emerged through discussions. The conventional teaching methods fail in many ways to provide an effective teaching environment for the changing generation. The increasing data needs new ways of approach to transforming incompetent traditional methods. Creativity flourishes with the assistance of computer technologies and their increasing data.

\subsection{The outlook of design education}

Design education exposed to transform with the observation of the society. It comprises evolving design information, teaching methods, and its instruments. Y1ldırım [12] describe design education as an environment where information transferred to the students immediately. MacAllister [7] remarks that the inadequacy of the implicit design methodology has caused students to lose interest in the design process. Design education has two main components. The first part is the studio education, and the second is the theoretical courses. The studio education can be both teacher and student-based teaching methods. The theoretical courses mostly use the teacher-based method. The teacher-based method failed to update itself to current developments in the society and technology.

\subsection{Teaching methods}

Design education implies many abilities to their prospective students. Students learn to form a conceptual project in a studio environment. Studio environment reflects the education strategy of the design institution. The failures of the design education affect the performance of the future architects. The argument here is to emphasize that the traditional teaching methods are no longer enough to trade with the growing large data sources in the design field.

\subsection{Increasing data}

Nowadays, there are many methods to compile the various data for any subject. The numerous data use can improve the quality level of the driven subject. In design education, design diviners in charge of the organization of the curriculum; have to develop suitable solutions to handle the bulky heavy data load. The countless sources of data enlarge the coverage area of the design discipline in many aspects. However, the traditional teaching methods of design keep its constancy.

\subsection{Changing generation}

Design information excluding basic principles of design develops every passing day. The education tools have also a rapid changing pattern, thanks to the developments in the technological field. While, we (researchers and educationists) accept and try to keep up a pace with all these changes. We still disregard the fact that the learners are also variable being "changing generation" by maintaining design education techniques almost intact for ages. 


\subsection{Research methodologies}

Research methodologies improve the quality of knowledge that influences the design education. Haddad [4] describes the design concept development based on reviews of scholarly researches that can be used to bring forth new ideas and approaches to design problems.

\subsection{Creativity}

There are some "alternative teaching methods" and schools applied in design. However, the schools "adapting" the same approach for design courses, regardless of being theoretical or practical have still an overwhelming majority around the globe. Even though such equality and uniformity may seem to be an advantage for "Bologna process" or similar studies in many departments/fields of the social or applied sciences, it impedes the skills blossoming as well as obstructing the students to acquire information in majors of design where the "creativity" is supposed to be up in the front.

\section{Reshaping the design education}

Design education in the past criticized more about its quality rather than used methods. One reason is the quality of the design educations have direct affect the designers' success in practice. Nowadays, the conventional design education can no longer sustain the changing new generation. The discussions extend to teaching methods, managing the increasing data, developing research methodologies and the creativity. There are some attempts to reshape the design education; yet, it will take some time to analyse the end results. Many experts agree on the fact that any new attempts must consider sustainable approaches.

Teaching methods have an important role to provide interactions between the students and academics. Depending on new methods, the traditional lecture hall, classrooms, studio spaces, etc., need further amendments (Fig. 1). The seating arrangements in study space should be arranged for the benefits of the new teaching methods. The computers, cell phones, pads etc. are tools giving access to increasing data. Large data help to minimize the future mistakes. The educator's role at this stage is to develop strategies to handle the large data. Tools may change rapidly in time, but the methods will evolve in time with their excessive use. Besides using research methodologies to develop the design philosophies and instruments, we need to apply the same for unearthing perceptions and skills of changing generation. In light of the data obtained, research methodologies should be produced in line with:

- adapt to changing technologies,

- changing design concepts, and also

- changing generation. 

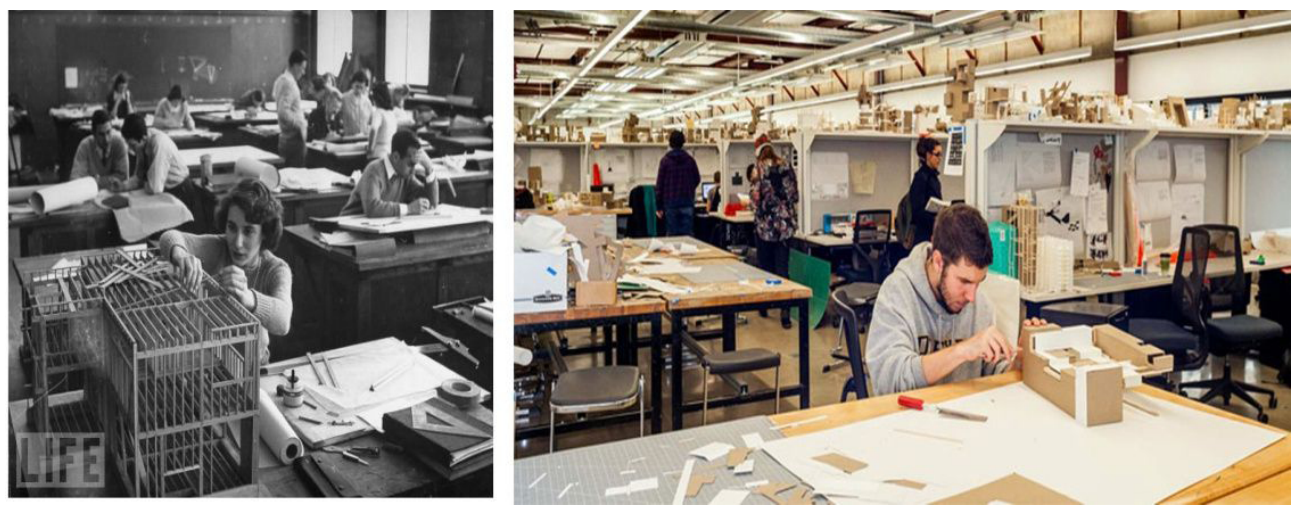

Fig. 1. (a) Mid 1900's Old Style Studio [13] (b) 2000's Traditional Studios [14]

Research methodologies will help handling and streaming in orderly fashion all novelties of the design that seem to be disintegrated for the time being.

This also challenges the educators to be a part of this continuous change and development. If the educator is to make himself/herself a part of this research, then, it becomes easier to adapt and deliver the education in line with three variables that is already known to him/her. "Creativity" is the most important factor in the design. All researches, findings, technology developments and all methods developed to teach them serve for such creating and producing process. Thus, the techniques developed should not kill, but feed the creativity of the learner.

\section{Conclusion}

Design education is on the threshold of a transmutation. Any attempts in action need to perform deep analysis over the changing society and the academic environment. Creativity and correctly acquired and continuously upgraded knowledge may help enjoying more efficient design process. Thus, the outcomes of such process will be more satisfactory for both the designer and the user as they will be more successful in responding to the questions in the intellects of the parties.

Innovation and variations in design sail for infinite choices together with developing research methods, changing skilled generation and developing technologies.

\section{References}

1. Asce, Menzel, K., Hartkopf, V., \& Ilal, M., E. Collaborative Learning and Design in Architecture, Engineering, and Construction. In CINET2013 Conference Proceedings (pp. 309-337), (2013).

2. Bashier, F. Reflections on architectural design education: The return of rationalism in the studio. Frontiers of Architectural Research, 3(4), 424-430. http://doi.org/10.1016/j.foar.2014.08.004. (2014).

3. Embaby, M. E. Heritage conservation and architectural education: "“ An educational methodology for design studios ."” HBRC Journal, 10(3), 339-350. http://doi.org/10.1016/j.hbrcj.2013.12.007, (2014).

4. Haddad, R. Research and Methodology for Interior Designers. Procedia - Social and Behavioral Sciences, 122, 283-291. http://doi.org/10.1016/j.sbspro.2014.01.1343, (2014). 
5. Jamieson, P., Fisher, K., Gilding, T., Taylor, P. G., \& Trevitt, a. C. F. Place and Space in the Design of New Learning Environments. Higher Education Research \& Development, 19(2), 221-236. http://doi.org/10.1080/072943600445664, (2000).

6. Lapadula, M. I., \& Quiroga, C. Heritage as a pedagogical resource and platform for exploration in architectural design education. The Journal of Architecture, 17(4), 591607. http://doi.org/10.1080/13602365.2012.709028, (2012).

7. McAllister, K. The design process-making it relevant for students. in design education: exploration and prospects for a better built enviroment. In: Ashraf, M., Salama, Crosbie, Micheal J. (Eds.), Archnet-IJAR, International Journal of Architectural Research, vol. 4; 2010, pp. 76-89 (July and November 2010), 2010.

8. Purcell, a. T., \& Gero, J. S. Drawings and the design process. Design Studies, 19(4), 389-430. http://doi.org/10.1016/S0142-694X(98)00015-5, (1998).

9. Tzonis, A. A framework for architectural education. Frontiers of Architectural Research, 3(4), 477-479. http://doi.org/10.1016/j.foar.2014.10.001, (2014).

10. Yavuz, A. Ö., \& Bülüç, E. Proposing a Model Developed by Rule based Approaches in Architectural Design Education. Procedia - Social and Behavioral Sciences, 143, 334338. http://doi.org/10.1016/j.sbspro.2014.07.415, (2014).

11. Yazıcıoğlu, D. A. The Integration of Interior Architecture Education With Digital Design Approaches. Education, 8(5), 637-658, (2011).

12. Yildirim, T., Yavuz, A. O., \& Kirci, N. Experience of Traditional Teaching Methods in Architectural Design Education: "Mimesis Technique." Procedia - Social and Behavioral Sciences, 51, 234-238. http://doi.org/10.1016/j.sbspro.2012.08.151, (2012).

13. http://www.urbanrealm.com/blogs/index.php/2010/05/24/50494128-jpg?blog=12 2015.

14. http://drexel.edu/ /media/Images/westphal/dept/arch/slideshow/2014/DrexelArch_Con text02.ashx?la=en\&hash=25D541AB8705A185C06DFA7240CB96CCA3DCA50F , 2015. 